\title{
Flavonoids uptake and their effect on cell cycle of human colon adenocarcinoma cells (Caco2)
}

\author{
M Salucci*,', LA Stivala', G Maiani', R Bugianesi' and V Vannini' ${ }^{2}$ \\ 'National Institute of Food and Nutrition Research, Via Ardeatina 546, 001 78, Rome, Italy; ${ }^{2}$ Department of Experimental Medicine, Unit of General Pathology, \\ University of Pavia, P.za Botta 10, 27100, Pavia, Italy
}

Green tea, mainly through its constituents epigallocatechin gallate, epigallocatechin, epicatechin gallate and epicatechin, has demonstrated anticarcinogenic activity in several animal models, including those for skin, lung and gastro-intestinal tract cancer, although less is known about colorectal cancer. Quercetin, the major flavonoid present in vegetables and fruit, exerts potential anticarcinogenic effects in animal models and cell cultures, but less is known about quercetin glucosides. The objectives of this study were to investigate (i) the antioxidant activity of the phenolic compounds epicatechin, epigallocatechin gallate, gallic acid and quercetin-3-glucoside; (ii) the cytotoxicity of different concentrations of epicatechin, epigallocatechin gallate, and gallic acid; (iii) the cellular uptake of epicatechin, epigallocatechin gallate, gallic acid and quercetin-3-glucoside and (iv) their effect on the cell cycle. Human colon adenocarcinoma cells were used as experimental model. The results of this study indicate that all dietary flavonoids studied (epicatechin, epigallocatechin gallate, gallic acid and quercetin-3-glucoside) show a significant antioxidant effect in a chemical model system, but only epigallocatechin gallate or gallic acid are able to interfere with the cell cycle in $\mathrm{Caco} 2$ cell lines. These data suggest that the antioxidant activity of flavonoids is not related to the inhibition of cellular growth. From a structural point of view, the galloyl moiety appears to be required for both the antioxidant and the antiproliferative effects.

British Journal of Cancer (2002) 86, 1645 - 165I. DOI: 10.1038/sj/bjc/6600295 www.bjcancer.com

(c) 2002 Cancer Research UK

Keywords: Caco2; flavonoids; antioxidant activity; cell cycle

Epidemiological studies from around the world have consistently reported that a high intake of fruit and vegetables is associated with a low incidence of most types of cancer (Wang et al, 1989; Dragsted et al, 1993). It is estimated that about $70 \%$ of all cancers are attributable to the diet. Colorectal cancer is the second most prevalent cancer in the developed world (Parkin et al, 1985). Western diet with a high intake of calories from fat and low fibre supply has been linked to an increase of colon cancer incidence, whilst vegetarian or mediterranean diets are more protective (Vargas and Alberts, 1992). Several compounds have been identified in plants which have well recognised antioxidant properties, such as carotenoids, ascorbic acid, $\alpha$-tocopherol and flavonoids (Block et al, 1992; Hertog et al, 1992) and inhibit cancer development.

Thus, the use of natural substances, that are derived from the diet for chemoprevention, might provide a strategy to inhibit the development of cancer. Green tea, mainly through its constituents epigallocatechin gallate (EGCG), epigallocatechin (EGC), epicatechin gallate (ECG) and epicatechin (EC), has demonstrated anticarcinogenic activity in several animal models, including those for skin, lung and gastro-intestinal tract cancer (Katiyar et al, 1992; Yang and Wang, 1993). Several recent studies (Berger et al, 2001; Uesato et al, 2001) on the effect of green tea polyphenolics on colon cancer cell lines have shown antiproliferative activity. Controversial results have been obtained by other authors on animal model (Hirose et al, 2001) and on human model (Nagano et al,

*Correspondence: M Salucci; E-mail: salucci@inran.it

Received 8 October 200 I; revised 4 March 2002; accepted II March 2002
2001). In vitro studies (Komori et al, 1993) have shown that green tea can arrest the growth of human mammary and lung cancer cell lines. New data (Cao et al, 1999) indicate that EGCG suppresses endothelial cell growth in vitro and the formation of new blood vessels in chick chorioallantoic membrane; drinking green tea significantly prevents corneal vascularisation induced by one of the most potent angiogenetic factors (VEGF). The same results have been obtained by Jung et al (2001) in in vitro studies, in serum-deprived HT29 cells, and in in vivo studies, on the growth of HT29 cells in nude mice. EGCG exerts, at least part of its anticancer effect, by inhibiting angiogenesis through blocking the induction of VEGF in both in vitro and in vivo studies, while EGC, ECG and EC have not demonstrated the same effect (Jung et al, 2001). However, green tea extract has a stronger effect on cell growth than the major phenolic component, EGCG (Komori et al, 1993). Recently, another study (Suganuma et al, 1999) has demonstrated a synergic effect of EGCG and EC in the cell line PC-9, inhibiting growth.

Quercetin and its glucosides are the major flavonoids present in vegetables, in particular fresh onions, fruit (Hertog et al, 1992; 1993) and beverages (Kiviranta et al, 1988). Animal (Deschner et al, 1991; Yang et al, 2000) and in vitro studies suggest that quercetin exerts a preventive effect against cancer (Kawaii et al, 1999), but less is known about quercetin glucosides. Hollman et al (1995) show that $52 \%$ of the quercetin glucosides from onions was absorbed, whereas only $24 \%$ of free quercetin was absorbed in human model. It would therefore appear that the quercetin glucosides are better absorbed than the free aglycone. However, the specific role of individual phenols in carcinogenesis has been and still is very unclear due to controversial results. 
The objectives of this study were to investigate (i) the antioxidant activity of the phenolic compounds EC, EGCG, gallic acid (GA) and quercetin-3-glucoside (IQ); (ii) the cytotoxicity of different concentrations of EC, EGCG, and GA; (iii) the cellular uptake of EC, EGCG, GA and IQ; and (iv) their effect on the cell cycle. Human colon adenocarcinoma (Caco2) cells were used as experimental model. These cells, chosen because of their great capacity to differentiate at confluence and to display specialised enterocyte/colonocyte cell function, express many intestinal enzymes such as sucrase, maltase, gammaglutamyltransferase and aldehyde deydrogenase comparable with normal colonic mucosal activity (Koivisto and Salaspuro, 1997) and retain the ability to transport vitamins, ions and glucose (Pinto et al, 1983).

\section{MATERIALS AND METHODS}

\section{Chemicals}

Nonidet P-40, propidium iodide (PI), RNase A, bromodeossiuridine (BrdU), Tween 20, tris- $\mathrm{HCl}, \mathrm{MgCl}_{2}, \mathrm{HCl}$, L-glutamine ( $2 \mathrm{mM})$, streptomycin, penicillin, amphotericin B (fungizone), Rphycoerythrin (R-PE), bovine serum albumin (BSA), fluoresceinisothiocyanate (FITC)-conjugated anti-mouse antibody, sodium tetraborate, and phosphate buffer solution (PBS) were purchased from Sigma (Milan, Italy). Anti-BrdU monoclonal antibody was purchased from Dako (Denmark). Phenylmethylsulphonylfluoride (PMSF) and propidium iodide (PI) were purchased from BDH (Poole, UK). Foetal calf serum (FCS) was purchased from Gibco (UK). Dulbecco Modified Medium (D-MEM) was obtained from Bio-Whittaker (UK). Ammoniumiron(II)sulphatehexahydrate, xylenol orange sodium salt and hydrogen peroxide $\left(\mathrm{H}_{2} \mathrm{O}_{2}\right)$ were purchased from Aldrich (Milan, Italy). 2,2'-diazobis(2-amidinopropane) dihydrochloride (ABAP) was purchased from Wako (Società Italiana Chimici, Rome, Italy). EGCG, EC and GA were purchased from Sigma (Milan, Italy) while IQ was purchased from Extrasynthese (Societá Italiana Chimici, Rome, Italy). Ethanol and methanol were purchased from Carlo Erba (Milan, Italy). EGCG, EC, GA and IQ were dissolved in methanol. The final methanol concentration in the cell incubation medium was $0.1 \%$.

\section{Measurement of the antioxidant activity}

The antioxidant activity of EGCG, EC, GA and IQ was evaluated in vitro by measuring the total radical antioxidant potential (TRAP) according to Ghiselli et al (1995). This method is based on the protection afforded by the antioxidants present in the sample against the decay of a fluorescent target R-phycoerythrin (R-PE) during a controlled peroxidation reaction induced by the free radical generator 2,2'-diazobis(2-amidinopropane) dihydrochloride at $37^{\circ} \mathrm{C}$.

\section{Analysis of hydrogen peroxide}

In each sample (DMEM with and without $100 \mu \mathrm{M}$ of EGCG, $\mathrm{EC}, \mathrm{GA}$ and $70 \mu \mathrm{M} \mathrm{IQ})$ the formation of hydrogen peroxide $\left(\mathrm{H}_{2} \mathrm{O}_{2}\right)$ was assayed using the FOX2 reagent (ferrous in xylenol orange, version 2) according to the procedure of NouroozZadeh et al (1994). One hundred $\mu \mathrm{l}$ of sample was mixed with $900 \mu \mathrm{l}$ of FOX2 reagent, incubated at room temperature for $30 \mathrm{~min}$ in $1.5 \mathrm{ml}$ microcentrifuge vials, then centrifuged at $12000 \mathrm{~g}$ for $5 \mathrm{~min}$. Absorbance of the supernatant was then read at $560 \mathrm{~nm}$.

\section{Cell culture}

The human colon adenocarcinoma Caco2 cells were purchased from American type culture collection (Rockville, USA). Cells were cultured in D-MEM, supplemented with 15\% of FCS, L-glutamine
$(2 \mathrm{mM})$, streptomycin and penicillin $\left(100 \mu \mathrm{g} / 100 \mathrm{U} \mathrm{ml}^{-1}\right)$ and $2.5 \mu \mathrm{g} \mathrm{ml}^{-1}$ fungizone, and incubated at $37^{\circ} \mathrm{C}$ in a $5 \% \mathrm{CO}_{2}$ incubator. Cells were plated at a density of about $1 \times 10^{6}$ cells/flask and grown until reaching confluence.

\section{Cytotoxicity}

When the cells had reached the $60-70 \%$ of confluence, the growth medium was replaced with a medium containing $15 \%$ of FCS and various concentrations of EGCG, EC, and GA (100, 125, 250, $500 \mu \mathrm{M})$. Incubation with these phenolic compounds was performed for $24 \mathrm{~h}$. The toxicity of IQ was analysed up to the limit of solubility $(70 \mu \mathrm{M})$ and it was not toxic for the cellular line (data not shown). After the treatments, cells were washed twice with PBS, detached with a standard trypsinisation procedure and resuspended in PBS. The number of viable cells was determined by Trypan blue dye exclusion test.

\section{Cellular uptake}

To assess the cellular uptake, $\mathrm{Caco} 2$ cells were grown up to confluence and were incubated for 24,48 and $72 \mathrm{~h}$ with EC, EGCG, GA at $100 \mu \mathrm{m}$ and IQ at $70 \mu \mathrm{m}$. The flavonoid content of cells was analysed by high-performance liquid chromatography (HPLC) equipped with a Coularray detector (ESA 5600) consisting of eight coulometric array cells. After treatment, cells were detached using a standard trypsinisation procedure, counted by haemocytometer, transferred to plastic tubes and washed in PBS. The cell suspension was washed three times with distilled water and subsequently lysed by sonication. Then, EGCG, EC, GA and IQ were hydrolysed and extracted twice with ethylacetate. The organic phase was evaporated under a stream of nitrogen and resuspended in HPLC mobile phase (methanol: water $1: 1 \mathrm{v} \mathrm{v}^{-1}$ ) (Bugianesi et al, 2000). Aliquots $(30 \mu \mathrm{l})$ were injected onto the HPLC; the mobile phase was methanol and water acidified at pH 2.8 with orthophosphoric acid. The elution gradient was $13-87 \%$ methanol in $38 \mathrm{~min}$, with a flow rate of $1 \mathrm{ml} \mathrm{min}^{-1}$. The eight potentials were set from -80 to 200 for EGCG and EC and from 100 to 900 for IQ. The column used for separation was Supelcosil LC18, $25 \mathrm{~cm}$ in length and with an internal diameter of $2.1 \mathrm{~mm}$ (Supelco).

\section{Cell cycle analysis}

In order to study the effect on the cell cycle, four cell cultures were incubated with $100 \mu \mathrm{M}$ respectively of EC, EGCG, GA and $70 \mu \mathrm{M}$ IQ for $24 \mathrm{~h}$. Cell cycle distribution was assessed by determining BrdU incorporation vs DNA content. Cells were incubated with $30 \mu \mathrm{M}$ BrdU during the last hour of culture, harvested and fixed in cold $70 \%$ ethanol. Fixed cells were washed in PBS, resuspended in $2 \mathrm{~N} \mathrm{HCl}$ for $30 \mathrm{~min}$ at room temperature, pelleted and then resuspended in $0.1 \mathrm{~N}$ sodium tetraborate for $15 \mathrm{~min}$. The samples were then washed in PBS, incubated for $15 \mathrm{~min}$ in PBS containing $1 \%$ bovine serum albumin and $0.2 \%$ Tween 20 (PBT) and for $30 \mathrm{~min}$ in $100 \mu \mathrm{l}$ of anti-BrdU monoclonal antibody diluted 1:10 in PBT. After two washes with PBT, cells were incubated for $30 \mathrm{~min}$ with $100 \mu \mathrm{l}$ of fluoresceinisothiocyanate (FITC)-conjugated anti-mouse antibody diluted $1: 50$ in PBT, then washed twice and resuspended in PBS containing $5 \mu \mathrm{g} \mathrm{ml}^{-1}$ propidium iodide (PI) and $100 \mu \mathrm{g} \mathrm{ml}^{-1}$ of RNAse A. Cells were analysed with a Coulter Epics XL (Coulter Corp.) flow cytometer. The instrument was equipped with an argon laser tuned at $488 \mathrm{~nm}$ for fluorescence excitation. Propidium iodide (PI) fluorescence was measured with a $585 / 44$ or a $620 / 30 \mathrm{~nm}$ band-pass filter. Ten thousand cells were measured for each sample. Computer statistical analysis of mean fluorescence intensity (MFI) and graphic representation were performed with XL2 software (Coulter). 


\section{Statistics}

Statistical analyses were obtained by Anova test. For each analysis, at least three independent experiments were carried out. Data are given as the mean \pm s.d.

\section{RESULTS}

\section{Antioxidant activity}

TRAP values are shown in Table 1. Results are expressed as micromoles/l of peroxyl radicals scavenged by each antioxidant at the equimolar concentration $(100 \mu \mathrm{M})$. Despite the similar chemical structure of flavonoids studied (Figure 1), EGCG had the highest antioxidant activity against peroxyl radicals $(530.7 \mu \mathrm{M}, P<0.05)$ followed by IQ $(365.2 \mu \mathrm{M}$, at $70 \mu \mathrm{M})$, GA $(161.9 \mu \mathrm{M})$ and EC $(0.0 \mu \mathrm{M})$. Since $100 \mu \mathrm{M}$ EC did not show any detectable antioxidant activity, increasing concentrations (up to $200 \mu \mathrm{M}$ ) were also analysed. However, the TRAP value of $77.3 \mu \mathrm{M}$ obtained at the highest EC concentration of $200 \mu \mathrm{M}$ confirmed that this compound did not exert any antioxidant effect.

\section{Hydrogen peroxide production}

Table 2 shows the results obtained by the FOX2 assay. $\mathrm{H}_{2} \mathrm{O}_{2}$ generation was measured in the cell medium with and without

Table I Total antioxidant capacity of single antioxidant compound

\begin{tabular}{lcc}
\hline Antioxidant compounds & Concentration $(\mu \mathbf{M})$ & TRAP $(\mu \mathbf{M})$ \\
\hline EC & 200 & $77.3 \pm 6.2$ \\
EC & 100 & $0.0 \pm 0.0$ \\
EGCG & 100 & $530.7 \pm 15.6 *$ \\
IQ & 70 & $365.2 \pm 11.2$ \\
GA & 100 & $161.9 \pm 8.8$ \\
\hline
\end{tabular}

The antioxidant activity of EGCG, EC, GA and IQ was measured by TRAP and was analysed according to Ghiselli et al, 1995. Three independent experiments were made and the results represent the mean \pm s.d. $* P<0.05$ (Anova test).

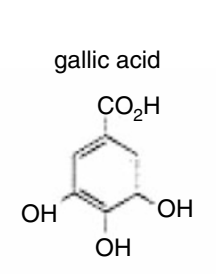

quercetin epicatechin<smiles>Oc1cc(O)c2c(c1)OC(c1ccc(O)c(O)c1)C(O)C2</smiles>

$$
\text { epigallocatechin gallate }
$$<smiles>O=C(OC1Cc2c(O)cc(O)cc2OC1c1cc(O)c(O)c(O)c1)c1cc(O)c(O)c(O)c1</smiles>

Figure I Chemical structure of flavonoids studied. The figure shows gallic acid, catechin, quercetin and epigallocatechin gallate. IQ: quercetin with $\mathrm{R}_{2}=\mathrm{D}$-glucoside in the 3-position. EGCG differs from EC in having a galloyl moiety in the 3-position. addition of phenolic compounds. We observed insignificant production of $\mathrm{H}_{2} \mathrm{O}_{2}(<2 \mu \mathrm{M}$ after $2 \mathrm{~h})$ in presence of phenols with respect to control medium, under our experimental conditions.

\section{Cytotoxicity study}

The threshold for toxicity was determined for each of the specified flavonoids. Figure 2 shows the toxicity, as evaluated by the Trypan blue test, for different concentrations of EC, EGCG and GA (100, $125,250,500 \mu \mathrm{M})$ in Caco 2 cells after $24 \mathrm{~h}$ of incubation. The results are expressed as percentage of viable cells with respect to the survival of control cells. EC, EGCG and GA were found to be non toxic at the concentrations ranging between $100-250 \mu \mathrm{M}$ with a cellular survival of $70-80 \%$, whereas a $60 \%$ cytotoxicity occurred at $500 \mu \mathrm{M}$ concentration of all flavonoids tested.

\section{Cellular uptake}

Figure 3 shows the time of course of cellular uptake of EC, EGCG, GA $(100 \mu \mathrm{M})$ and IQ $(70 \mu \mathrm{M})$ after 24,48 and $72 \mathrm{~h}$ of incubation. Results are expressed as ng $10^{6}$ cells.

Epicatechin is taken up by Caco2 cells achieving levels of $0.43 \pm 0.22 \mathrm{ng} / 10^{6}$ cells after $24 \mathrm{~h}$ of incubation and reaching a value of $3.50 \pm 2.2 \mathrm{ng} / 10^{6}$ cells after $72 \mathrm{~h}$ of incubation. The final uptake of EGCG was comparable to that of EC $(3.11 \pm 2.3 \mathrm{ng} /$ $10^{6}$ cells at $72 \mathrm{~h}$ ) but reached this level earlier, at $48 \mathrm{~h}$. In contrast, IQ was less readily absorbed compared to EC or EGCC, reaching a maximum of $0.50 \pm 0.20 \mathrm{ng} / 10^{6}$ cells after $48 \mathrm{~h}$, and disappearing at $72 \mathrm{~h}$.

GA was not detectable, both in the medium and in the cells, after 24, 48 and $72 \mathrm{~h}$ of incubation. This result was perplexing as GA exerts a clear effect on cell cycle parameters. Considering that

Table $2 \quad \mathrm{H}_{2} \mathrm{O}_{2}$ generation in cell-culture medium (DMEM) after addition of phenolic compounds

\begin{tabular}{lccccc}
\hline & \multicolumn{4}{c}{$\mathbf{H}_{\mathbf{2}} \mathbf{O}_{\mathbf{2}}$ present in medium $(\mu \mathbf{M})$} & \\
\cline { 2 - 5 } Time $(\mathbf{m i n})$ & EGCG & EC & GA & IQ & Medium \\
\hline 0 & $1.25 \pm 0.04$ & $1.29 \pm 0.01$ & $1.27 \pm 0.03$ & $1.22 \pm 0.04$ & $1.22 \pm 0.02$ \\
30 & $1.41 \pm 0.03$ & $1.36 \pm 0.04$ & $1.52 \pm 0.06$ & $1.37 \pm 0.05$ & $1.30 \pm 0.06$ \\
60 & $1.50 \pm 0.02$ & $1.38 \pm 0.13$ & $1.52 \pm 0.01$ & $1.35 \pm 0.11$ & $1.25 \pm 0.03$ \\
90 & $1.52 \pm 0.06$ & $1.35 \pm 0.07$ & $1.56 \pm 0.03$ & $1.35 \pm 0.08$ & $1.27 \pm 0.01$ \\
120 & $1.55 \pm 0.18$ & $1.35 \pm 0.09$ & $2.14 \pm 0.93$ & $1.34 \pm 0.08$ & $1.29 \pm 0.08$ \\
\hline
\end{tabular}

DMEM was treated with $100 \mu \mathrm{M}$ of EGCG, EC, GA and $70 \mu \mathrm{M}$ of $1 \mathrm{Q}$ for $30,60,90$, $120 \mathrm{~min}$, and the $\mathrm{H}_{2} \mathrm{O}_{2}$ production was analysed using the $\mathrm{FOX} 2$ reagent. Three independent experiments were made and the results represent the mean \pm s.d.

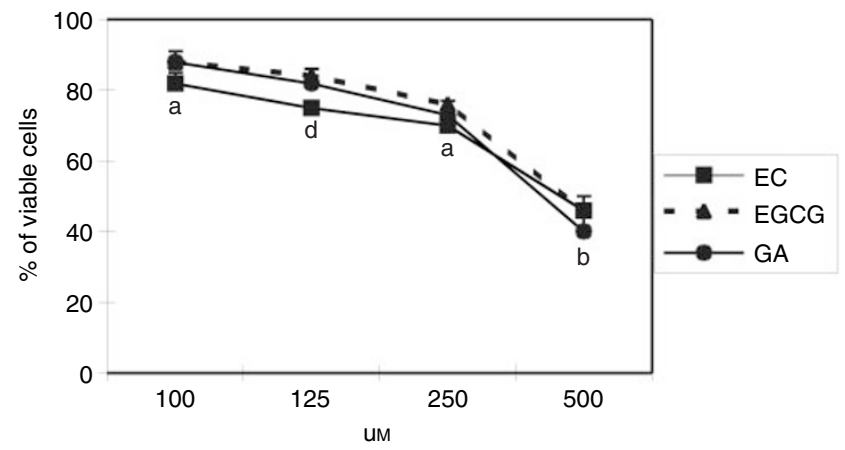

Figure 2 Cytotoxicity of selected flavonoids on $\mathrm{Caco} 2$ cell in culture. Cells were incubated with different concentrations of EGCG, EC, GA and IQ for $24 \mathrm{~h}$ and the number of viable cells was determined by Trypan blue test. Three independent experiments were made. Bars indicate standard deviation of the mean. a vs $b \quad P<0.05$ (Anova test). 
it could be due to rapid degradation or binding of GA to a component of the medium, and/or a rapid metabolism, we measured the GA content both in the Caco2 cells and in the medium after 0,10 , $30,60 \mathrm{~min}$ and $24 \mathrm{~h}$ of incubation. Table 3 shows a $90 \%$ reduction of GA in the medium within $24 \mathrm{~h}$ of incubation. Similarly, Figure 4 shows that GA is readily taken up by cells and virtually disappears after $60 \min \left(0.004 \mu \mathrm{g} / 10^{6}\right.$ cells $)$.

\section{Effect of flavonoids on cell cycle progression}

The distribution of cells in each phase of the cell cycle after incubation for $24 \mathrm{~h}$ with $100 \mu \mathrm{M}$ EC or EGCG or $70 \mu \mathrm{M}$ of IQ, was determined using flow cytometry to quantitative DNA content (Figure 5). Results are expressed as percentage of cells in each phase of cell cycle.

EGCG and GA significantly increased the number of cells in G2/ M phase $(P<0.05)$, with a consequent reduction of cells in $\mathrm{G} 1$ and $\mathrm{S}$ phases. In fact, after $24 \mathrm{~h}$ of incubation, the number of cells in G2/M phase was increased by about 33 and $40 \%$ for EGCG and GA, respectively. On the contrary, responses to EC and IQ were similar to those of control cells. Figure 6 shows the dot plots of BrdU immunofluorescence vs DNA content in control Caco2 and in cells treated with EGCG, GA, EC or IQ for $24 \mathrm{~h}$. The results show that cells treated with EGCG or GA incorporate significantly a lower amount of BrdU than control cells. Quantitative analysis of BrdU immunofluorescence, in the region corresponding to cells in $S$ phase, indicated an inhibition in BrdU incorporation as a result of cells treated with the above flavonoids being delayed in G2/M phase.

\section{DISCUSSION AND CONCLUSION}

A variety of micronutrients from plant products have been identified as compounds with potential anticarcinogenic properties. Among these micronutrients, phenolic compounds in food, and

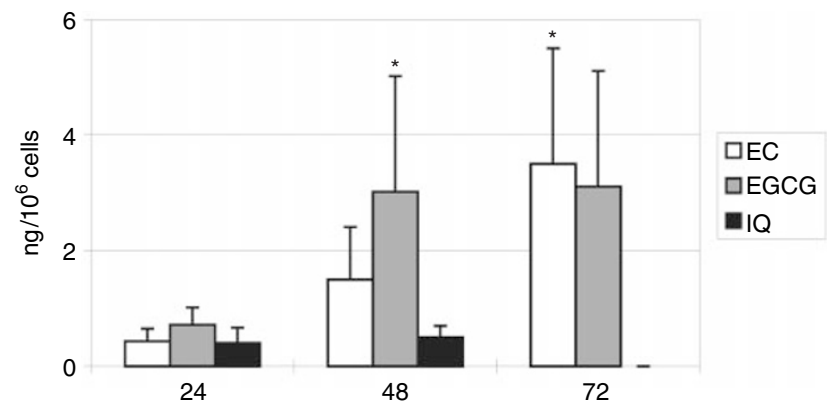

Figure 3 Time course of cellular uptake of EC, EGCG and IQ on Caco2 cells. Cells were incubated for 24, 48 and $72 \mathrm{~h}$ with $100 \mu \mathrm{M}$ of EGCG, EC and with $70 \mu \mathrm{M}$ of IQ, and the cellular uptake was analysed by HPLC. Three independent experiments were made. Bars indicate standard deviation of the mean. $* P<0.05$ (Anova test).

Table 3 GA in medium after different incubation times

\begin{tabular}{lcc}
\hline Time of incubation & Medium+GA $(\mu \mathrm{M})$ & Medium \\
\hline T0 min & $100 \pm 0.68$ & - \\
T10 min & $80 \pm 0.01$ & - \\
T30 min & $74 \pm 0.43$ & - \\
T60 min & $49 \pm 0.03$ & - \\
T24 h & $11 \pm 0.55$ & - \\
T48 h & $0.01 \pm 0.001$ & - \\
\hline
\end{tabular}

DMEM was incubated with $100 \mu \mathrm{M}$ of EGCG, EC, GA and $70 \mu \mathrm{M}$ of IQ for 10, 30, $60 \mathrm{~min}$ and $24,48 \mathrm{~h}$. The GA content was analysed by HPLC. Three independent experiments were made and the results represent the mean \pm s.d.

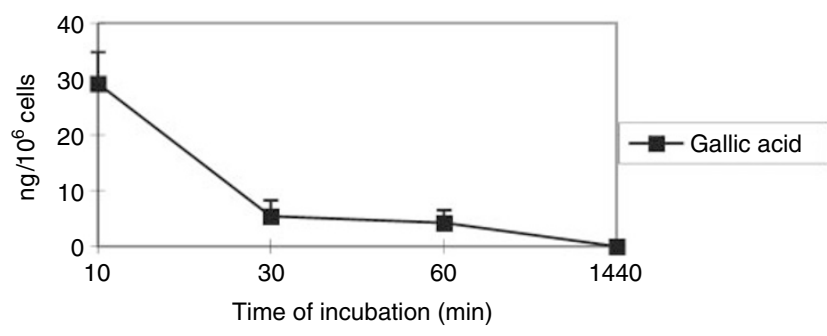

Figure 4 Time course of cellular uptake of GA on Caco2 cells. Cells were incubated with $100 \mu \mathrm{M}$ of GA for 10, 30, $60 \mathrm{~min}$ and $24 \mathrm{~h}$, and the cellular uptake was evaluated by HPLC. Three independent experiments were made. Bars indicate standard deviation of the mean.

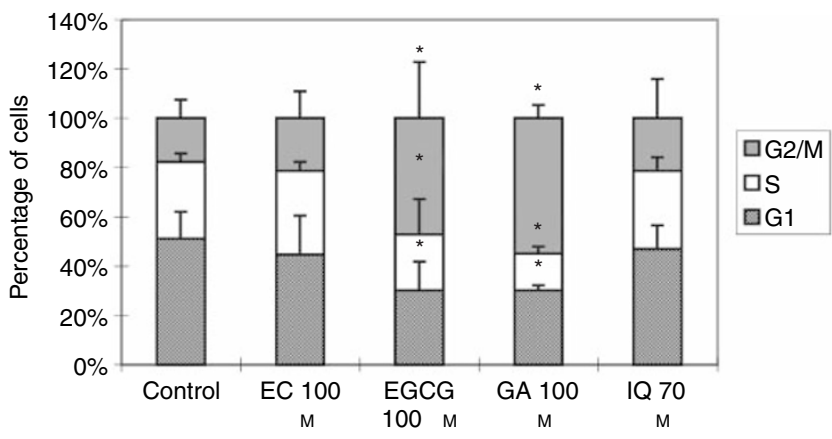

Figure 5 Effect of selected flavonoids on the cell cycle of $\mathrm{Caco} 2$ cells Cells were incubated without or with $100 \mu \mathrm{M}$ of EGCG, EC, GA and with $70 \mu \mathrm{M}$ of IQ for $24 \mathrm{~h}$, and the percentage of cells in each phase of the cell cycle was assessed by flow cytometry. Three independent experiments were made. Bars indicate standard deviation of the mean. $* P<0.05$ (Anova test).

especially flavonoids, may exert a protective role against colon cancer. Although, there is much strong evidence to support this healthy effect of flavonoids in human and animal models, there is little knowledge about their bioavailability. The current flavonoid intake in Northern Europe has been estimated at around 50$150 \mathrm{mg} \mathrm{day}{ }^{-1}$ for total flavonoids (Hollman and Arts, 2000). Generally less than $1 \%$ of the total amount ingested reaches the systemic circulation, and absorption commonly ranges from 0.2 to $0.5 \%$. Most flavonoids are present in the diet as glycosides (Scalbert and Williamson, 2000), and quercetin and its glucosides have been the most extensively studied forms. Their absorption in man and in animal model is however a matter of controversy.

Although there are some studies of the absorption of EC and EGCG from green tea in human volunteers (Lee et al, 1995; Maiani et al, 1997) and animal models (Crespy et al, 1999) there are no reports on cellular absorption in the literature. This study assesses, for the first time, the uptake of the three free flavonoids EC, EGCG, GA and one flavonoid glucosides (IQ) in Caco2 cells. We observed a different uptake of each flavonoid studied in relation to their different chemical structure and to the position of glucose moiety. The EC content in cells steadily increased over $72 \mathrm{~h}$ of incubation, while cellular EGCG reached a maximum after $48 \mathrm{~h}$ of incubation. In the case of GA no detectable uptake by cells was observed after 24, 48 and $72 \mathrm{~h}$. However, this was shown to be due to a rapid depletion of GA in the medium; 50\% loss after $1 \mathrm{~h}$ and a maximum of $90 \%$ after $24 \mathrm{~h}$. Cells were shown to rapidly take up GA within $10 \mathrm{~min}$ of the start of incubation. Considering the high reactivity of GA, it could be further metabolised or the metabolite bound to a medium component.

In the case of IQ we observed a rapid uptake by cells after $24 \mathrm{~h}$ of incubation, although its magnitude was lower than for the other 

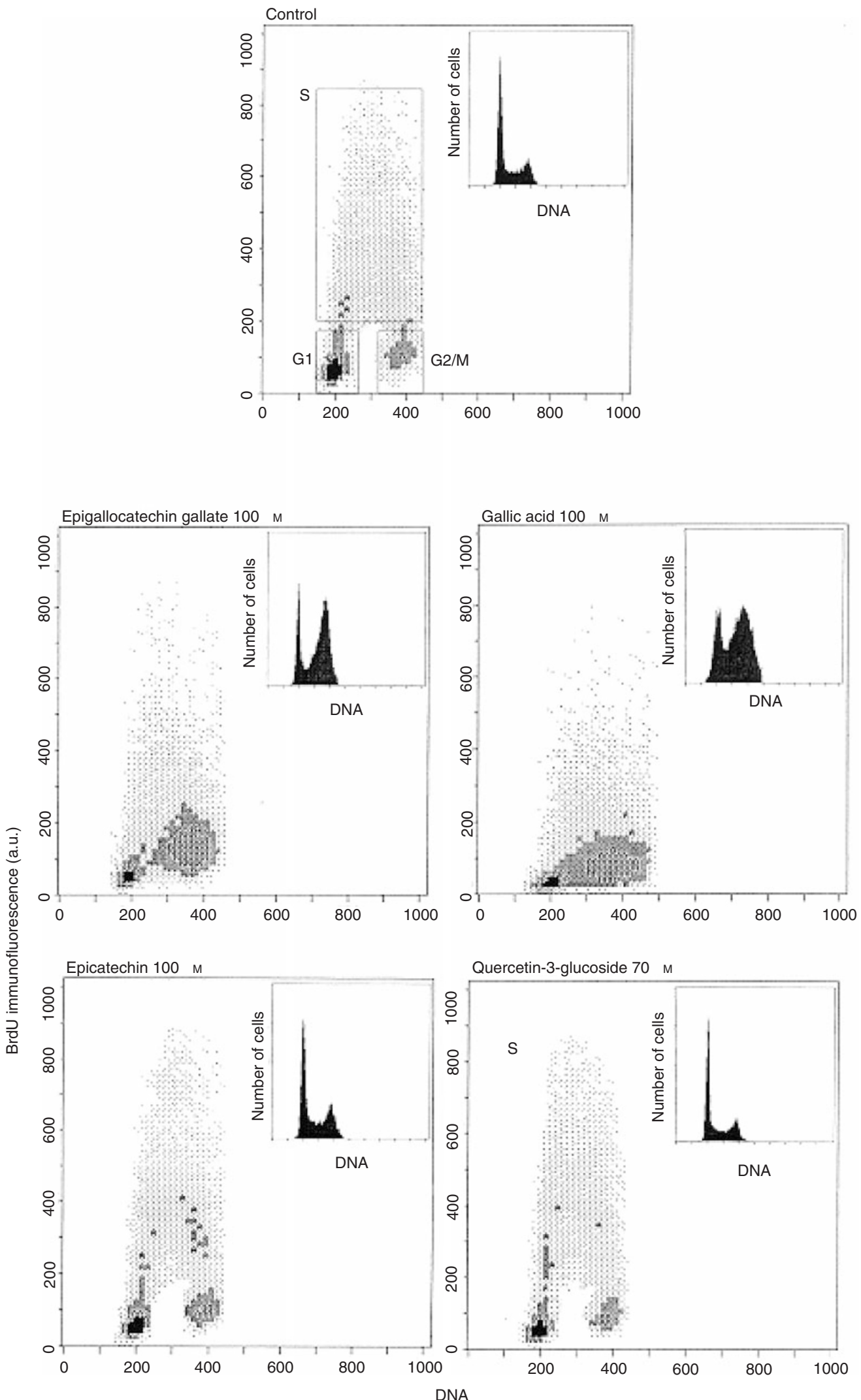

Figure 6 Frequency distributions of BrdU immunofluorescence vs DNA content in untreated and treated cells. Cells were incubated without and with $100 \mu \mathrm{M}$ of EGCG, EC, GA and $70 \mu \mathrm{M}$ of IQ for $24 \mathrm{~h}$, and the percentage of cells in each phase was measured by flow cytometry. Three independent experiments were made. 
three flavonoids. This is in agreement with hypotheses from two studies on the absorption of IQ in humans and in isolated rat intestine. Day et al (1998) demonstrated the presence of a cytosolic $\beta$-glucosidase in human small intestine having a high affinity for quercetin-4'-glucoside and genistein-7-glucoside but a low affinity for quercetin-3-glucoside. Furthermore, Gee et al (1998) showed an interaction between quercetin-3-glucoside and the sodium dependent glucose transporter (SGLT1) in rat intestine. Walgren et al (1998), working with cultures of $\mathrm{Caco} 2$ cells, evaluated the transport of quercetin and its glucosides, mainly quercetin- $4^{\prime}$ glucoside, quercetin-3,4'-diglucoside. These authors showed that transport depended on the position and nature of glucosidic moiety and hypothesised that a glucose moiety in the 3-position could promote absorption and vice versa with respect to glycosylation at the $4^{\prime}$-position. Recently, the same authors (Walgren et al, $2000 \mathrm{a}, \mathrm{b})$ have demonstrated for the first time that quercetin- $4^{\prime}$ glucoside is transported by SGLT1 across the apical membrane of enterocytes. However, its trancellular absorption is limited by a multidrug resistance-associated protein MRP2 mediated efflux across the apical membrane as well as by an unknown transporter on the basolateral membrane. Despite a direct evidence about the transport of quercetin-4'-glucoside (Gee et al, 1998; Walgren et $a l, 2000 \mathrm{a}, \mathrm{b})$ there are some controversial results that require further research.

A number of investigators have reported that flavonoids inhibit the tumour growth by interfering with some phases of the cell cycle. Green tea extract and quercetin have been the most extensively studied agents. Quercetin shows anti-proliferative effects against various cancer cell lines (Yoshida et al, 1990), markedly inhibiting the proliferation of gastric and colon cancer cells and arresting the cell cycle at G1 phase. Moreover, quercetin was found to inhibit the cell growth of leukaemia T-cells (Yoshida et al, 1992), Ehrlich ascite tumour cells (Suolinna et al, 1975) and NK/Ly ascite tumour cells. Agullo et al (1994) have demonstrated that quercetin has potent cytotoxicity against colon cancer cells in vitro, and that this is associated with antiproliferative activity. Literature data (Khafif et al, 1998) show a synergistic chemopreventive effect between EGCG and curcumin on the cell cycle of premalignant and malignant human oral epithelial cells. Flow cytometric studies have showed that EGCG and curcumin inhibited growth by different mechanisms; EGCG blocked all cells in the $G_{1}$ phase, whereas curcumin blocked cells in $S / \mathrm{G}_{2} \mathrm{M}$ phases. Another study (Suganuma et al, 1999) has showed a synergistic effect between EC and EGCG on cell growth inhibition and on inhibition of TNF- $\alpha$ release, an endogenous tumour promoter of human lung cancer cell line PC-9. Ahmad and Mukhtar (1999) have reported that EGCG induced apoptosis and cell cycle arrest in human carcinoma cells. These results suggest that green tea polyphenols, particularly EGCG, can act as antitumour, promoters, antiproliferators, be anti-inflammatory, and may be useful for cancer chemoprevention (Liang et al, 1999).

Our study shows that EGCG and GA induce a cell cycle delay in Caco 2 cells. Treatments with $100 \mu \mathrm{M}$ EGCG and GA increased the percentage of cells in $\mathrm{G}_{2} / \mathrm{M}$ phase by 33 and $40 \%$ respectively, whilst $100 \mu \mathrm{m}$ EC and $70 \mu \mathrm{M}$ quercetin-3-glucoside, which do not contain a galloyl moiety did not inhibit the progression of

\section{REFERENCES}

Agullo G, Gamet L, Besson C, Demignè C, Rèmèsy C (1994) Quercetin exerts a preferential cytotoxic effect on active dividing colon carcinoma HT29 and Caco 2 cells. Cancer Lett 87: 55-63

Ahmad N, Mukhtar H (1999) Green tea polyphenols and cancer: biologic mechanisms and practical implications. Nutr Rev 57: 78-83 the cell cycle. We also observed a decrease in $\mathrm{G}_{1}$-phase cell associated with an accumulation in $\mathrm{G}_{2} / \mathrm{M}$ phase. These data confirm the findings of Okabe et al (1997) in human lung cancer cell line PC9 incubated with the same concentration of EGCG.

A link between cell cycle arrest and antioxidant capacity has been postulated for EGCG and GA. We have also evaluated the ability of EGCG and GA to scavenge free radicals (measured as TRAP). The relative order of decreasing efficiency was EGCG $>$ IQ $>$ GA $>$ EC suggesting a possible correlation for EGCG but not for GA. Thus, the apparent antioxidant activity of flavonoids does not relate to the inhibition of cell growth as also observed by Kuntz et al (1999).

Another possible mechanism by which the anticarcinogenic activity of the flavonoids may be mediated, could be the induction of apoptosis. We therefore determined the frequency of apoptosis by monitoring the typical morphological changes of nuclear chromatin distribution after staining cells with Hoechtst 33258 dye. $\mathrm{Caco} 2$ cells incubated with flavonoids showed a similar pattern to control cells. Thus the flavonoids tested failed to induce apoptosis in our model system (data not shown).

Recently, Long et al (2000) have demonstrated that the addition of GA, EGCG, EC, quercetin and catechin to commonly used cell culture media leads to generation of substantial amounts of hydrogen peroxide $\left(\mathrm{H}_{2} \mathrm{O}_{2}\right)$. The authors suggested that $\mathrm{H}_{2} \mathrm{O}_{2}$ production by these phenolic compounds could be responsible of their effect on cells. Particularly, the gallate moiety seems especially important, since GA and EGCG generated substantial amounts of $\mathrm{H}_{2} \mathrm{O}_{2}$. However, we have measured the $\mathrm{H}_{2} \mathrm{O}_{2}$ production in our samples and no significant generation of $\mathrm{H}_{2} \mathrm{O}_{2}$ was observed, comparable results being obtained with and without addition of phenolic compounds.

In conclusion, the results of this study indicate that, among dietary flavonoids studied, EGCG or GA are able to interfere with the cell cycle in a Caco2 cell line, and that EGCG, IQ and GA show a significant antioxidant effect in a chemical model system. From a structural point of view, the galloyl moiety appears to be required both for the antioxidant and antiproliferative effects.

The fact that the intestinal epithelium can be exposed to high concentration of dietary flavonoids, implies that these compounds could have an important role in the prevention of colon cancer through the inhibiting the cell cycle of epithelial cells. However, the in vitro inhibition of growth of cancer cell line does not necessarily infer down regulation of growth of the entire epithelium in vivo.

Moreover, the protective effect of fruit and vegetables as a whole could be greater than any one single phenolic compound, probably due to the presence of many antioxidants that could, together, potentiate this effect.

\section{ACKNOWLEDGEMENTS}

The authors thank Dr Patrizia Sommi, Dr Monica Savio and Mrs Elena Azzini for their technical assistance during the study. The authors also thank Mrs Lara Palomba for her assistance during the preparation of the paper.
Berger SJ, Gupta S, Belfi CA, Gosky DM, Mukhtar H (2001) Green tea constituent ( - )-epigallocatechin-3-gallate inhibits topoisomerase I activity in human colon carcinoma cells. Biochem Biophys Res Commun 288: $101-$ 105 
Block G, Patterson B, Subar A (1992) Fruit, vegetables and cancer prevention: a review of epidemiological evidence. Nutr Cancer 18: 1-29

Bugianesi R, Serafini M, Simone F, Wu D, Meydani S, Ferro-Luzzi A, Azzini E, Maiani G (2000) High-performance liquid chromatography with coulometric electrode array detector for the determination of quercetin levels in cells of the immune system. Anal Biochem 284: 296-300

Cao Y, Cao R (1999) Angiogenesis inhibited by drinking tea. [letter] Nature 398: 381

Crespy V, Morand C, Manach C, Besson C, Demigne C, Remesy C (1999) Part of quercetin absorbed in the small intestine is conjugated and further secreted in the intestinal lumen. Gastrointest Liver Physiol 40: G120-G126

Day AJ, DuPont MS, Ridley S, Rhodes M, Rhodes MJC, Morgan MRA, Williamson G (1998) Deglycosylation of flavonoid and isoflavonoid glycosides by human small intestine and liver $\beta$-glucosidase activity. FEBS Lett 436: 71

Deschner EE, Ruperto J, Wong G, Newmark HL (1991) Quercetin and rutin as inhibitors of azoxymethanol-induced colonic neoplasia. Carcinogenesis 12: $1193-1196$

Dragsted LO, Strube M, Larsen JC (1993) Cancer-protective factors in fruits and vegetables: biochemical and biological background. Pharmacol Toxicol (Suppl 1): $121-146$

Gee JM, DuPont MS, Rhodes MJC, Johnson IT (1998) Quercetin glucosides interact with the intestinal glucose transport pathway. Free Rad Biol Med 25: $19-25$

Ghiselli A, Serafini M, Maiani G, Azzini E, Ferro-Luzzi A (1995) A fluorescence method for measuring total plasma antioxidant capability. Free Rad Biol Med 18: $29-36$

Hertog MGL, Hollman PCH, Katan MB (1992) Content of potentially anticarcinogenic flavonoids of 28 vegetables and 9 fruit commonly consumed in the Netherlands. J Agric Food Chem 40: 2379-2383

Hertog MGL, Freskensen EJM, Hollman PCH, Katan MB, Kromhout D (1993) Dietary antioxidant flavonoids and risk of coronary heart disease: the Zutphen Elderly study. Lancet 342: 1007 - 1011

Hirose M, Hoshiya T, Mizoguchi Y, Nakamura A, Akagi K, Shirai T (2001) Green tea catechins enhance tumor development in the colon without effects in the lung or thyroid after pretreatment with 1,2-dimethylhydrazine or 2,2'-dihydroxy-di-n-propylnitrosamine in male F344 rats. Cancer Lett 168: $23-29$

Hollman PCH, de Vries JHM, van Leeuwen SD, Mengelers MJB, Katan MB (1995) Absorption of dietary quercetin glycosides and quercetin in healthy ileostomy volunteers. Am J Clin Nutr 62: 1276-1282

Hollman PCH, Arts ICV (2000) Flavonols, flavones and flavanols-nature, occurrence and dietary burden. J Scien Food Agric 80: $1081-1093$

Jung YD, Kim MS, Shin BA, Chay KO, Ahn BW, Liu W, Bucana CD, Gallick GE, Ellis LM (2001) EGCG, a major component of green tea, inhibits tumor growth by inhibiting VEGF induction in human colon carcinoma cells. Br J Cancer 84: $844-850$

Kawaii S, Tomono Y, Katase E, Ogawa K, Yano M (1999) Antiproliferative activity on several cancer cell lines. Biosci Biotechnol Biochem 63: 896-899

Katiyar SK, Agarwal T, Mukhtak H (1992) Green tea in chemoprevention of cancer. Compr Ther 18: 3-8

Khafif A, Schantz PS, Chou TC, Edelstein D, Sacks GP (1998) Quantitation of chemopreventive synergism between (-)-epigallocatechin-3-gallate and curcumin in normal, premalignant and malignant human oral epithelial cells. Carcinogenesis 19: 419-424

Kiviranta J, Houvinen K, Hiltunen R (1988) Variation of phenolic substances in onion. Acta Pharm Fenn 97: 67-72

Koivisto T, Salaspuro M (1997) Effect of acetaldehyde on brush border enzyme activities in human colon adenocarcinoma cells line Caco2. Alcohol Clin Exp Res 21: 1599-1605

Komori A, Yatsunami J, Okabe S, Abe S, Hara K, Suganuma M, Kim SJ, Fujiki H (1993) Anticarcinogenic activity of green tea polyphenols. Jpn J Clin Oncol 23: $186-190$

Kuntz S, Wenzel U, Daniel H (1999) Comparative analysis of the effects of flavonoids on proliferation, cytotoxicity, and apoptosis in human colon cancer cell lines. Eur J Nutr 38: $133-142$
Lee M-J, Wang Z-Y, Li H, Chen L, Sun Y, Gobbo S, Balentine DA, Yang CS (1995) Analysis of plasma and urinary tea polyphenols in human subjects. Cancer Epidemiol Biomarkers Prev 4: 393-399

Liang YC, Chen YC, Lin YL, Shiau SYL, Ho CT, Lin JK (1999) Suppression of extracellular signals and cell proliferation by the black tea polyphenol, theaflavin-3,3'-digallate. Carcinogenesis 20: $733-736$

Long LH, Clement MV, Halliwell B (2000) Artifact in cell culture: rapid generation of hydrogen peroxide on addition of $(-)$-epigallocatechin, $(-)$-epigallocatechin gallate, (+)-catechin, and quercetin to commonly used cell culture media. Biochem Biophys Res Commun 273: 50-53

Maiani G, Serafini M, Salucci M, Azzini E, Ferro-Luzzi A (1997) Application of a new high-performance liquid chromatographic method for measuring selected polyphenols in human plasma. J Chrom B 692: $311-317$

Nagano J, Kono S, Preston DL, Mabuchi K (2001) A prospective study of green tea consumption and cancer incidence, Hiroshima and Nagasaki (Japan). Cancer Causes Control 12: $501-508$

Nourooz-Zadeh J, Tajaddini-Sarmadi J, Wolff SP (1994) Measurement of plasma hydroperoxide concentrations by the ferrous oxidation-xylenol orange assay in conjunction with triphenylphosphine. Anal Biochem 220: $403-409$

Okabe S, Suganuma M, Hayashi M, Sueoka E, Komori A (1997) Mechanisms of growth inhibition of human lung cancer cell line, PC-9. Jpn J Cancer Res 88: $639-643$

Parkin DM, Pisani P, Ferlay J (1985) Estimates of the world-wide incidence of eighteen major cancers. Int J Cancer 54: 594-606

Pinto M, Robin L S, Appay MD, Kedinger M, Triadon N, Dussanlxx E, La Croix B, Zweibaum A (1983) Enterocyte-like differentiation and polarisation of the human colon carcinoma cell line Caco2 in culture. Biol Cell 47: $323-330$

Scalbert A, Williamson G (2000) Dietary intake and bioavailability of polyphenols. J Nutr 130: 2073S-2085S

Suganuma M, Okabe S, Kai Y, Sueoka N, Sueoka E, Fujiki H (1999) Synergistic effect of $(-)$-epigallocatechin gallate with $(-)$-epicatechin, sulindac, or tamoxifen on cancer-preventive activity in the human lung cancer cell line PC-9. Cancer Res 59: 44-47

Suolinna EM, Buchsbaum RN, Racker E (1975) The effect of flavonoids on aerobic glycolysis and growth of tumor cells. Cancer Res 35: 1865-1872

Uesato S, Kitagawa Y, Kamashimoto M, Kumagai A, Hori H, Nagasawa H (2001) Inhibition of green tea catechins against the growth of cancerous human colon and hepatic epithelial cells. Cancer Lett 170: $41-44$

Vargas PA, Alberts DS (1992) Primary prevention of colorectal cancer through dietary modification. Cancer 70: 1229-1235

Yang CS, Wang ZY (1993) Tea and cancer. J Natl Cancer Inst 85: 1038-1049

Yang K, Lamprecht SA, Liu Y, Shinozaki H, Fan K, Leung D, Newmark H, Steele VE, Kelloff GJ, Lipkin M (2000) Chemoprevention studies of the flavonoids quercetin and rutin in normal and azoxymethane-treated mouse colon. Carcinogenesis 21: $1655-1660$

Yoshida M, Sakai T, Hosokawa N, Marni N, Matsumoto K, Fujioka A, Nishino M, Aoike A (1990) The effect of quercetin on cell cycle progression and growth of human gastric cancer cells. FEBS Lett 260: 10-13

Yoshida M, Yamamoto M, Nikado T (1992) Quercetin arrests human leukemic T-cells in late G1 phase of the cell cycle. Cancer Res 52: 6676-6681

Walgren RA, Walle UK, Walle T (1998) Transport of quercetin and its glucosides across human intestinal epithelial Caco-2 cells. Bioch Pharmacol 55: $17721-17727$

Walgren RA, Karnaky KJ, Lindermayer GE, Walle T (2000a) Efflux of dietary flavonoid quercetin $4^{\prime}$ - $\beta$-glucoside across human intestinal Caco- 2 cell monolayers by apical multidrug resistance-associated protein-2. J Pharmacol Exp Ther 294: $830-836$

Walgren RA, Lin J-T, Kinne K-H, Walle T (2000b) Cellular uptake of dietary flavonoid quercetin $4^{\prime}$ - $\beta$-glucoside by sodium-dependent glucose transporter SGLT1. J Pharmacol Exp Ther 294: 837-843

Wang ZY, Khan WA, Bickers DR, Mukhtar H (1989) Protection against polycyclic aromatic hydrocarbon-induced skin tumor initiation in mice by green tea polyphenols. Carcinogenesis 10: $411-415$ 